Manchester, and in 1897 took a post at the Jenner Institute of Preventive Medicine (which later became the Lister Institute). There he began his fruitful investiga. tions of fermentation, and in particular of the yeast juices first prepared by Buchner. Although when kept warm the enzymes from yeast liquefied cell walls while the autolysed liquid still contained zymase, it was expocted that, on heating, the enzymes would be destroyed. Harden, however, showed that boiled fluid or extract could increase fermentation due to the presence of a 'co-enzyme' containing phosphates: on adding potassium phosphate a vigorous fermentation set in. He was thus able to show how cell-free juice could be separated into co-zymase and apo-zymase. From this he developed the concept of ferment and co-ferment. He went on to show the relation between $a_{0}$ hexose and phosphate-the enzyme reacting with phosphate being named 'phosphatase'-and discovered soveral ester-like 'sugar phosphates'. Apart from directing the biochemical division of the Lister Institute and holding a chair at London, Harden edited the Biochemical Journal and wrote many text-books. He was awarded the Davy Medal and shared the Nobel Prize with Euler-Chelpin, who carried on Harden's work on heat-stable co-enzymes and purified the co-enzyme of zymase.

\section{Science in France}

THE October-November 1964 issue of Nouvelle Frontier (No. 8) is of exceptional interest for a series of articles on the politics of seience. G. Palewski writes on science and national independence; A. Lobartho on a crusade for science; and F. Le Lionnais on the pattern of research. the organization of research in France is described by $P$. Frédet, and P. Piganiol writes on intornational scientific co-operation. Under the title "Research and Power", F. Maintenon discusses the duel betwoen the United States and the U.S.S.R. P. Cognard deals with research and planning, and $R$. Goussault with manpower problems under the title "Investment in Man", while P. Aigrin deals with research and defence. There are also short articles on nuclear research, space research and research in biology and in eloctronics. Some problems of scientific policy are also considered in an article in $L e$ Progrès Scientifique for May 1965 (No. 84), the preceding issue of which (No. 83, April 1965) is devoted mainly to a review of the situation and perspectives of biological and medical research in France, but includes also the text of a survey of biological and medical research in Europe by R. P. Grant, C. P. Huttner and C. C. Metzner, published in Science for October 23, 1964.

\section{The British Glass Industry Research Association}

THE tenth annual report of the British Glass Industry Research Association has recently been published (Fp. 42. Sheffield: The British Glass Industry Research Association, 1965). It records some important economic and technical develcpments for the year under review, not the least of which is the materially improved financial position of the Association, due to substantial sums of money emanating from the Department of Scientific and Industrial Research, the Ministry of Aviation, and the Electricity Council. The latter two sponsor special research projects: the former on the mechanism of strengthening of glass, the latter on investigating ways of facilitating the introduction of electric melting. On the technical side, the chief subjects considered in the report of the director of research, Dr. R. G. Newton, are: improvement of furnace life; heat utilization in furnaces; improvements in methods of founding glass; investigation of thermal conditions during glass-forming operations; improved strength in glass and glass articles; analysis of glasses and raw materials; and service behaviour of glass articles. One research achievement is emphasized in this report; this concerns the mechanism of upward-drilling of refractories which has now been elucidated so convincingly that a ciné-film has been prepared to show exactly how it takes place in furnaces; this subject is described in some detall undor the heading "Improvement of Furnace Life" in the dircctor's report. The Association continues to maintain its valuable information service and, besides research, its miscellaneous work includes some consultative testing, testing of safety glass, surveys of lighting conditions in factories, and statistical analyses.

\section{The Wildfowl Trust}

THE annual roport of the Wildfowl Trust for 1963-64 is a record of remarkable growth and success (Edited by Hugh Boyd. Fp. $136+32$ photographs. Illustrated by Peter Scott. Slimbridge, Gloucester shire: The Wildfowl Trust, 1965). In four yeals the numbor of visitors has increased by 50 per cent. Finances are satisfactory, and the facilities for research continue to improve and increase in extent The number of imaginative ventures to further the aims of the Trust increases each year, and, as an example, the report describes the identification competition for schools. This was held at the New Grounds on March 7 in bitterly cold weather. Sixty-four boys and girls from sixteen schools took part. Leighton Park again entered several strong teams and had three teams in the first five places in the Senior Competition; their $A$ team won the tirst prize from Monmouth, thus reversing the previous year's result. In the middle age-group a team from Acklam Hall, who had travelled 260 miles from Middlesbrough, came first, with Winchester second. The junior prize was won by Gloucester Girls High School by one point from Beaudesert Park. Besides full details of the collections, the report describes research and conservation initiated and carried out by members of the staff. It also contains articles by distinguishod contributors on research and conservation in various countries overseas. The photographs and drawings are of the usual high standard, although, perhaps, Peter Scott has excelled all his former efforts with his coloured cover drawing; it deserves separate publication.

\section{Careers with Instruments}

Careers with Instruments is a pamphlet prepared by the Society of Instrument Technology and is, in fact, a guide to both school-leavers and graduates who may be considering a working life in the fields of measurement, automatic control, data handling and computation, all implying training and competence in the use of modern instruments (Pp. 24. Society of Instrument Technology, $20 \mathrm{Peel}$ Street, London, W.8, April 1965. 2s. 6d.). The underlying theme of this pamphlet is that measurement and control serve and are served by all sciences and technologies; in effect, there is a two-way relationship between such disciplines as physics, mathematics, chemistry, electronics, nucleonics, chemical-, civil-, electrical-, mechanical- and production-engineering, also medicine, and measurement and control. The training pattern and prospects in this vocation are clearly set out and described, whether the starting-point be a secondary modern school, grammar school, or apprenticeship in the industry; it takes care of advancement via colleges of further education, technical colleges, colleges of advanced technology, and university qualifications. 'T hus are fashioned crafismen, technicians, or persons capable of filling responsible technical posts, and so on, subject to acquisition of City and Guild Final Certificate, Highor National Certificate or Diploma, or institutional recognition, whichever best fits the particular course of higher education chosen by the individual until he or she achieves h:s or her ultimate goal. The instrument world is, at the present time, well co-ordinated in Britain by such organizations as the Worshipful Company of Scientific Instrument Makers; the Society of Instmiment Technology; various associations of manufacturers, such as the British Industrial Measuring and Control 